$12-21-2020$

\title{
Gender, Age, and Survival of Italian Jews in the Holocaust
}

Susan Welch

The Pennsylvania State University

Follow this and additional works at: https://digitalcommons.usf.edu/gsp

\section{Recommended Citation}

Welch, Susan (2020) "Gender, Age, and Survival of Italian Jews in the Holocaust," Genocide Studies and Prevention: An International Journal: Vol. 14: Iss. 3: 110-128.

DOI:

https://doi.org/10.5038/1911-9933.14.3.1772

Available at: https://digitalcommons.usf.edu/gsp/vol14/iss3/10

This Articles is brought to you for free and open access by the Open Access Journals at Digital Commons @ University of South Florida. It has been accepted for inclusion in Genocide Studies and Prevention: An International Journal by an authorized editor of Digital Commons @ University of South Florida. For more information, please contact digitalcommons@usf.edu. 


\section{Gender, Age, and Survival of Italian Jews in the Holocaust}

\section{Acknowledgements}

An earlier version of the paper was presented at the 77th Annual Meeting of the Midwest Political Science Association, Chicago, Illinois, April 3-6, 2019. I would like to thank Emily Kiver and Ron Filippelli, both of Penn State, and previous reviewers of the article for their assistance. 


\section{Introduction}

Though scholars of genocide have addressed the role of gender in these horrors, scholars of the Holocaust have only recently examined this issue. Fear of seeming to minimize the horrors of the Holocaust for all Jews made discussions of gender differences "irrelevant and even irreverent," as one writer remarked. ${ }^{1}$ Death for all Jews was the aim of the Germans and their allies, whether the Jews were male or female, young or old. And yet, as in all other aspects of life and death, gender and age mattered. "Even though the Germans were committed to sending all Jews to their deaths, for a variety of reasons women and men traveled toward that destination on distinct roads," 2 Nechama Tec has written. I will examine those distinct roads by looking at sex differences in deportation and survival of Italian Jews with a particular focus on the intersection of gender with age.

\section{Gender and the Holocaust}

Previous research has illuminated some aspects of the influence of gender on Jewish life and death in the Holocaust. As more survivors came forward to tell their stories and as women's history became more mainstream, the discussion of the experiences of women in the ghettoes, labor camps, and in hiding became more frequent. ${ }^{3}$ Most of the work that has been done on the role of gender in the Holocaust is based on personal testimonies through interviews, diaries and autobiographies, ghetto histories, and other textual records and have focused on changes that each stage of the Holocaust brought about in women's and men's roles and on sexual violence. ${ }^{4}$

Very little of what we know about gender is based on larger collections of information. Indeed, until recently, most empirical social science, including political science, has avoided the study of the Holocaust entirely despite its centrality to other interests of political scientists. ${ }^{5}$ It may be that scholars believed that translating the horrors of the Holocaust into facts and figures somehow diminished the inhumanity of what was done. Or they believe that the overall numbers are so horrific, nothing can be learned by studying them. ${ }^{6}$

But Tec's "distinct roads"7 have many branches that need to be explored. Geographers of the Holocaust have described the gendered nature of many of the Holocaust's important sites and processes, including the transports that carried millions and in so doing led to the

1 Joan Ringelheim, "The Split between Gender and the Holocaust," in Women in the Holocaust, ed. Dalia Ofer and Lenore J. Weitzman (New Haven: Yale University Press, 1998), 344.

2 Nechama Tec, Resilience and Courage: Women, Men and the Holocaust (New Haven: Yale University Press, 2004), 12.

${ }^{3}$ Myrna Goldenberg and Amy Shapiro, eds., Different Horrors, Same Hell: Gender and the Holocaust (Seattle: University of Washington Press, 2013); Raul Hilberg, Perpetrators, Victims, Bystanders: The Jewish Catastrophe 1933-1945 (New York: Harper Collins, 1992); Dalia Ofer and Lenore J. Weitzman, eds., Women in the Holocaust (New Haven: Yale University Press, 1999); Carol Rittner and John K. Roth, eds., Different Voices: Women and the Holocaust, 1st ed. (New York: Paragon House, 1993); Pascale Rachel Bos, "Women and the Holocaust: Analyzing Gender Differences," in Experience and Expression: Women, the Nazis, and the Holocaust, ed. Elizabeth R. Baer and Myrna Goldenberg (Detroit: Wayne State University Press, 2003).

4 See, for example, works cited in footnotes 1,2, and 3.

${ }^{5}$ See Charles King, “Can There Be a Political Science of the Holocaust?," Perspectives on Politics 10, no. 2 (2012), 323-341, accessed November 3, 2020.

${ }^{6}$ Lewi Stone, "Quantifying the Holocaust: Hyperintense Kill Rates during the Nazi Genocide," Science Advances 5, no. 1 (January 2019), accessed November 2, 2020, https:/ / doi.org/10.1126/ sciadv.aau7292.

7 Tec, Resilience and Courage, 12.

Susan Welch. "Gender, Age, and Survival of Italian Jews in the Holocaust." Genocide Studies and Prevention 14, no. 3, 110-128. https://doi.org/10.5038/1911-9933.14.3.1772.

(c) 2020 Genocide Studies and Prevention. 
separation of men from women and broke families apart. ${ }^{8}$ Whether Jews were in ghettos or camps, or on trains, or hiding in forests, gender mattered. In almost every setting, women were more vulnerable and able to be exploited even as they took on new roles outside the home as workers and, often, as representatives of their families. 9 Throughout the war, women were at risk for rape and sexual violence. Many were forced to trade sex for survival; and the rape of Jewish women by both German soldiers and rescuers was, if not common, certainly not rare. ${ }^{10}$

Demography was also at the root of those distinct roads. Jewish women, like gentile ones, were in the majority of their communities in most countries that fought in World War I.11 The "women surplus" was a much-discussed social phenomenon during the interwar years. In Italy, in 1931, there were 792 men for every 1,000 women in the population. ${ }^{12}$

And women were an increasing proportion of the Jewish population in nations under Nazi control. ${ }^{13}$ For example, Jewish women were $52 \%$ of the German Jewish population in 1933, but 58\% in 1939.14 This increasing imbalance occurred partially because women were more likely to stay behind to take care of elderly relatives or other family members, while men had more opportunities and incentives to emigrate. ${ }^{15}$ A majority of those emigrating from Germany were men. ${ }^{16}$ Men were subject to greater physical threats during Kristallnacht and in the early part of the war. They were more likely to be rounded up and deported to labor camps. In this early period, men were more likely to commit suicide. ${ }^{17}$

Gender differences were most striking among the aged. Of elderly widows and widowers left in Germany and Austria in 1939, more than $80 \%$ were women. ${ }^{18}$

8 Tim Cole, Holocaust Landscapes (London: Bloomsbury, 2016).

${ }_{9}$ Carol Mann, "The Gender Dimension of the Holocaust in France," in Women and Genocide, ed. JoAnn DiGeorgio-Lutz and Donna Gosbee (Toronto: Women's Press, 2016), 73-102; Tec, Resilience and Courage.

10 Myrna Goldenberg, "Sex-Based Violence and the Politics and Ethics of Survival," in Different Horrors, Same Hell: Gender and the Holocaust, ed. Myrna Goldenberg and Amy H. Shapiro (Seattle, Washington: University of Washington Press, 2013), 99-131; Sonja M. Hedgepeth and Rochelle G. Saidel, eds., Sexual Violence against Jewish Women during the Holocaust, 1st ed. (Lebanon: Brandeis University Press, 2010); Zoe Waxman, "Rape and Sexual Abuse in Hiding," in Sexual Violence against Jewish Women during the Holocaust, ed. Sonja M. Hedgepeth and Rochelle G. Saidel, 1st ed. (Lebanon: Brandeis University Press, 2010); Alana Fangrad, Wartime Rape and Sexual Violence: An Examination of the Perpetrators, Motivations, and Functions of Sexual Violence against Jewish Women during the Holocaust (Bloomington: AuthorHouse, 2013).

11 David V. Glass, "Fertility Trends in Europe since the Second World War,” Population Studies 22, no. 1 (March 1968), 104, accessed November 2, 2020, https:// doi.org/10.2307/2173355.

12 Ibid.

13 Raul Hilberg, "Men and Women," in Perpetrators, Victims, Bystanders: The Jewish Catastrophe 1933-1945, Part II Victims (New York: Harper Collins, 1992), 126-130.

14 Marion Kaplan, "Keeping Calm and Weathering the Storm: Jewish Women's Responses to Daily Life in Nazi Germany, 1933-1939," in Women in the Holocaust ed. Dalia Ofer and Lenore J. Weitzman (New Haven: Yale University Press, 1999), 50.

15 Doris Bergen, "What Do Studies of Women, Gender, and Sexuality Contribute to Understanding the Holocaust," in Different Horrors, Same Hell: Gender and the Holocaust, ed. Myrna Goldenberg and Amy Shapiro. (Seattle: University of Washington Press, 2013), 16-37; Kaplan, Keeping Calm; Sybil Milton, "Women and the Holocaust: The Case of German and German-Jewish Women," in When Biology Became Destiny: Women in Weimar and Nazi Germany, ed. Renate Grossmann et al. (New York: Monthly Review Press, 1984).

16 Kaplan, Keeping Calm, 50-51. In 1936-37, 54\% of Jewish immigrants to the U.S. were men and during the 1933-1942 period, $52 \%$ of immigrants to Palestine were men. More than $92 \%$ of immigrants to Palestine in this period were Jewish. See Harry Seebee Linfield, "Statistics of Jews," The American Jewish Yearbook 45 (September 30, $1943-$ September 17, 1944), 600, accessed November 14, 2020, https:/ / www.jstor.org/stable/ 23602908.

17 Marion Kaplan, Between Dignity and Despair: Jewish Life in Nazi Germany (Oxford: Oxford University Press, 1999), 4650; Konrad Kwiet, "The Ultimate Refuge: Suicide in the Jewish Community Under the Nazis," The Leo Baeck Institute Yearbook 29, no. 1 (January 1984), 134-167, accessed November 2, 2020, https://doi.org/10.1093/leobaeck/ $\underline{29.1 .135}$

18 Kaplan, Keeping Calm, 50-51. 
Women were less likely to die from malnutrition and diseases caused by poverty, starvation, and filth. For example, in the Lodz ghetto, the male death rate was more than three times as great as the female in the 20-25 age group. ${ }^{19}$ Women were more likely than men to "pass" for Aryan and be able to hide among the Christian community. ${ }^{20}$

On the other hand, evidence suggests that women were more likely than men to be rounded up and slaughtered in mass killings and possibly sent to extermination camps. ${ }^{21}$ An analysis that examined gender differences in the destination of Jewish deportees from Western Europe to the east found that women were more likely than men to be sent to extermination camps, and at Auschwitz, to be murdered on arrival. By a small but significant margin, they were also less likely to survive the war. ${ }^{22}$

In most cases, we know little about gender differences in the locations where men and women were sent; the differences in the treatment of men and women as the war went on, and the relative fate of men and women sent to labor camps and ghettos.

\section{Age and the Holocaust}

The fate of the elderly has been told myriad times. Nazi principles called for death of those Jews unfit to work, and the elderly and the very young were both consigned to that category. ${ }^{23}$ "Selections" took place repeatedly: in ghettos, labor camps, and Auschwitz. ${ }^{24}$ Hundreds of survivor testimonies reveal their separation from their elderly parents or younger siblings upon arrival at Auschwitz, for example, and learning that they had been murdered within hours. ${ }^{25}$ Others report elderly and middle-aged parents being rounded up in local Aktionen ${ }^{26}$ while they, as working-age teens or young adults, survived, ${ }^{27}$ or watching a parent die on a death march, from starvation, violence, and disease. 28

We have only limited data on specific survival rates of older people on arrival at Auschwitz or through the war. Reportedly, $91 \%$ of prisoners over 51-years-old were murdered on arrival in a few transports of Jews from the Lens area of France to Auschwitz compared to 59\% of

${ }_{19}$ Michael Unger, "The Status and Plight of Women in the Lodz Ghetto," in Women in the Holocaust, ed. Dalia Ofer and Lenore J. Weitzman (Yale University Press, 1998), 123-142.

${ }^{20}$ Lenore Weitzman, "Living on the Aryan Side in Poland," in Women in the Holocaust, ed. Dalia Ofer and Lenore J. Weitzman (New Haven: Yale University Press, 1999), 187-188.

${ }^{21}$ Joan Ringelheim, "Women and the Holocaust: A Reconsideration of Research," in Different Voices: Women and the Holocaust, ed. Carol Rittner and John K. Roth (New York: Paragon House 1993), 374-406; Susan Welch, "Gender and Selection During the Holocaust: Transports of Western European Jews," Journal of Genocide Research 22, no. 4 (2020), 459-478, accessed November 14, 2020, https:// doi.org/10.1080/14623528.2020.1764743.

22 Welch, Gender and Selection.

${ }^{23}$ Christian Gerlach, The Extermination of the European Jews (Cambridge: Cambridge University Press, 2016), 197-198; Robert Jay Lifton, The Nazi Doctors: Medical Killing and the Psychology of Genocide, 2nd ed. (New York: Basic Books, 2017), 180-192.

${ }^{24}$ Christopher R. Browning, Remembering Survival: Inside a Nazi Slave-Labor Camp, 1st ed. (New York: W. W. Norton \& Company, 2010); see especially pages 74, 80, 94-95.

${ }^{25}$ Edith Eva Eger, The Choice: Embrace the Possible (New York: Scribner, 2017); Piera Sonnino, This Has Happened: An Italian Family in Auschwitz, trans. Ann Goldstein (New York: St. Martin's Griffin, 2006).

26 Aktionen (plural for Aktion, though many popular works use the anglicized Aktions) was the German word for the round ups of Jews in a community. Amidst violence and bloodshed, German security officials (often assisted by local police), rousted Jews from the homes, gathered them in a central place, and after hours or days marched or drove them somewhere locally to be murdered or transported them by trains to killing camps.

27 Sara Tuvel Bernstein, The Seamstress: A Memoir of Survival (New York: The Penguin Group, 1999); Gerda Weiss Klein, All But My Life: A Memoir (New York: Hill and Wang, 1957); Adina Blady Szwajger, I Remember Nothing More: The Warsaw Children's Hospital and the Jewish Resistance (New York: Pantheon, 1991).

${ }^{28}$ Eva Erben and David Lawson, Escape Story: How a Young Girl Survived the Holocaust (Birmingham: Sharron Publishing Services Ltd, 2011); Dawid Sierakowiak, The Diary of Dawid Sierakowiak: Five Notebooks from the Lódz Ghetto, ed. Alan Adelson, trans. Kamil Turowski (New York: Oxford University Press, 1998). 
those from the same transports aged 16-40.29 But beyond that, we have little information beyond anecdotal evidence about age differences in that first selection at Auschwitz or survival overall.

A study of survival rates of the Jews of Amsterdam based on comparing registries of Dutch Jews with lists of survivors and victims found no significant differences in survival of men and women but significant differences among age groups. ${ }^{30}$ The very youngest group (5years-old or younger) had a higher survival rate than other groups, and groups over thirty, and especially over 50, the lowest rates. ${ }^{31}$ Tammes' earlier study documented much higher survival rates among those less than 15 -years-old than among older adults, ${ }^{32}$ while his most recent complex analysis indicated that women and older people were more likely to die in the first three years of the war than men and younger people, but less likely after July 1943.33

But studies of survival in other locations are rare, if available at all. The scope of the Holocaust was so vast and data so incomplete. Just as with gender differences in survival, in most cases, we have little beyond anecdotal evidence to document age differences in survival.

\section{Italian Jews and the Holocaust}

Each country's experience during the war was unique, of course. Italy's was quite different from its Western European neighbors because, as an ally of Germany, Fascist Italy was not occupied until late in the war.

Italy's relatively small Jewish community is one of the oldest in the world. Many of the nearly 48,000 Italian Jews were descendants of families who had lived there during the Roman Empire. Others had ancestors who had fled there when expelled from Spain and Portugal in the late 15th century. On the other hand, as many as 10,000 were Jews from other countries who had migrated there before the war or fled as refugees during the 1930s. ${ }^{34}$

Most of those born in Italy were well assimilated into Italian society. In fact, about $10 \%$ of Italian Jews were members of the Fascist party, about the same percentage as the non-Jewish population. ${ }^{35}$ Others, however, were active in the resistance against the Fascists.

After signing an alliance agreement in 1937, and with only modest popular support, the Italian government promulgated a series of anti-Jewish measures starting in 1938. ${ }^{36}$ The new laws prohibited Italian Jews from holding public jobs, marrying non-Jews, owning large factories, attending public schools, or traveling freely. The Italian state "started down the path of state racism and antisemitism...." 37

29 Nicolas Mariot and Claire Zalc, Face à la persécution: 991 Juifs dans la guerre (Paris: Odile Jacob, Fondacion pour Mémoire de la Shoah, 2010), loc. 5099, Kindle.

30 Peter Tammes, "Surviving the Holocaust: Socio-Demographic Differences Among Amsterdam Jews," European Journal of Population 33, no. 3 (2017), 293-318, accessed November 2, 2020, https://doi.org/10.1007/s10680-016-9403-3.

31 Peter Tammes, "Survival of Jews during the Holocaust: The Importance of Different Types of Social Resources," International Journal of Epidemiology 36, no. 2 (April 2007), 330-335, accessed November 2, 2020, https://doi.org/ $\underline{10.1093 / \mathrm{ije} / \mathrm{dym} 006}$.

32 Ibid.

33 Tammes, Surviving the Holocaust.

34 Michele Sarfatti, The Jews in Mussolini's Italy: From Equality to Persecution, 1st ed., trans. John Tedeschi and Anne C. Tedeschi (Madison: University of Wisconsin Press, 2006), 24.

35 Susan Zuccotti, The Italians and the Holocaust: Persecution, Rescue, and Survival (Lincoln: University of Nebraska Press, 1996), $2-27$.

36 Susan Zuccotti, The Italians and the Holocaust: Persecution, Rescue, Survival (New York: Basic Books, 1986), 36-49. See also "Holocaust Encyclopedia Italy," United States Holocaust Memorial Museum, n.d., accessed September 24, 2020, https:/ / encyclopedia.ushmm.org/content/en/article/italy.

37 Simon Levis Sullam, The Italian Executioners: The Genocide of the Jews of Italy, trans. Oona Smyth and Claudia Patan (Princeton: Princeton University Press, 2018), 9. 
As long as Italy was a combatant in the war, the Italian government did not deport Jews nor threaten their lives despite the sanctions against them..$^{38}$ Foreign Jews in Italy were interned in both the small towns and concentration camps; ${ }^{39}$ but outside Italy, Italian troops largely protected Croatian Jews under their control along the Croatian coastline, Greek Jews in the part of their country occupied by Italy, and French Jews living in the southeast of France under Italian occupation. 40

In August 1943, King Victor Emmanuel removed Mussolini's Fascist government from power. When the new government signed a truce with the Allies the next month, German troops quickly entered Italy from the north, moving down the peninsula to occupy northern and central Italy and installing Mussolini as head of the Repubblica Sociale Italiana (RSI), also known as the Republic of Salo. Mussolini's government controlled the part of Italy occupied by Germany and German troops.

Jews were then at great risk. 97\% of Italian Jews lived in Rome and regions north of Rome. ${ }^{41}$ The Allies had invaded Sicily in July and mainland Italy in early September but were far south of Rome and meeting tremendous German resistance as they very slowly moved north. Most Jews who had been interned in southern Italy were safe but not the rest.

Once they were in Italy, the Germans moved quickly to imprison Jews and ship them to camps in the east. Transporting Jews by train to Eastern Europe to be murdered en masse was a key part of the Holocaust. ${ }^{42}$ By October 1943 when the Germans and their Italian collaborators began the roundup of Italian Jews, the Nazi murder camps-Belzec, Sobibor, and Treblinkahad already closed after killing more than 1.75 million Jews in just twenty-one months. ${ }^{43}$ Eighty percent of those Jews deported from Italy were transported to Auschwitz, both a killing center and a slave labor camp. ${ }^{44}$

The first to be sent were Jews living in Rome. In mid-October, the German SS captured more than 1,250 Roman Jews. ${ }^{45}$ Within two days they sent 1,020 of them to Auschwitz where nearly $60 \%$ of them were murdered immediately and almost all the rest were eventually murdered or died from starvation and disease during the next several months (only sixteen people survived). 46

38 Hilberg, Perpetrators, Victims, Bystanders, 421-432. Here, Hilberg describes the years of pressure by the German government on Mussolini to take more drastic steps.

${ }^{39}$ Most were confined to villages, but several camps were established too. See Carlo Spartaco Capogreco, "The Fascist Concentration Camps: From Internment to Deportation: Concentration Camps and Jews in Italy during World War II," Centro Primo Levi (blog), November 5, 2015, accessed October 29, 2020, https:// primolevicenter.org/printedmatter/the-fascist-concentration-camps/; Eric Lamet, A Child al Confino: The True Story of a Jewish Boy and His Mother in Mussolini's Italy (Avon: Adams Media, 2011); Sarfatti, The Jews in Mussolini's Italy; Zuccotti, The Italians and the Holocaust.

40 David Cesarani, Final Solution: The Fate of the Jews 1933-1949 (New York: St. Martin's Press, 2016); Robert O. Paxton, Vichy France: Old Guard and New Order, 1940-1944, 1st ed. (New York: Random House, 1972); Laurence Rees, The Holocaust: A New History, 1st ed. (New York: Penguin Books, 2017).

${ }^{41}$ Sarfatti, The Jews in Mussolini's Italy, 30.

42 A chilling examination of the horrors of the roundups, transit, and arrival of these deportation trains is found in Simone Gigliotti, The Train Journey: Transit, Captivity, and Witnessing in the Holocaust, 1st ed. (New York: Berghahn Books, 2009).

${ }^{43}$ Stone, Quantifying the Holocaust. These camps were constructed for the sole purpose of murdering Jews quickly and efficiently after the Wannsee conference had coordinated plans to murder all of Europe's Jews. See Mark Roseman, The Wannsee Conference and the Final Solution: A Reconsideration, 1st ed. (New York: Picador Paper, 2003); Gerhard Wolf, "The Wannsee Conference in 1942 and the National Socialist Living Space Dystopia," Journal of Genocide Research 17, no. 2 (April 2015), 153-175, accessed November 2, 2020, https://doi.org/ $\underline{10.1080 / 14623528.2015 .1027074 .}$

44 See Table 2 below.

${ }^{45}$ Zuccotti, The Italians and the Holocaust [1996], 101-138.

${ }^{46}$ Liliana Picciotto Fargion, Il Libro della Memoria: Gli Ebrei Deportati dall'Italia (1943-1945), 2nd ed. (Milano: Mursia, 1991), 59. 
These actions were legitimized by the Manifesto of Verona, written by the Congress of the Italian Fascist party meeting in November 1943, declaring that Jews were foreigners and enemies. This gave the imprimatur of the RSI to the roundups, deportation, and murder of Jews in Italy. ${ }^{47}$

After the arrest of Jews in Rome, ${ }^{48}$ the Italian police, or the German SS, or sometimes both, arrested Jews in other cities and towns. They were taken to local prisons or other sites nearby to be held until they could be deported. Many were sent on to a transit camp in Fossoli (near Carpi), Bolzano, or Trieste. A few hundred were sent to an RSI concentration camp in Borgo S. Dalmazzo in Piedmont. ${ }^{9}$ Piera Sonnino, for example, writes of her family's arrest in Genoa. ${ }^{50}$ The family's ancestors had lived in Italy for generations. On October 12, 1944, after being taken to a local Gestapo headquarters and questioned, the family was moved later that night to an Italian prison in Genoa, which Piera found shockingly primitive. They were imprisoned there for a week, then taken by truck to Bolzano. The next day, SS guards oversaw their journey to Auschwitz in sealed freight trains. ${ }^{51}$

Unlike the Sonninos, a large family with few resources, many native Italian Jews were able to hide in rural villages, in churches, or with friends. ${ }^{52}$ Nearly $90 \%$ escaped deportation. ${ }^{53}$ Foreign Jews were more vulnerable. Their networks with Christians were smaller and many could not speak Italian so hiding with natives was difficult. More than one-third of those Jews transported from Italy were foreign born. ${ }^{54}$

Ranging in size from a handful of prisoners to 1,020 people, 42 transports left Italy for Auschwitz (31 transports), Ravensbruck (5), Bergen-Belsen (4), Flossenberg (1), and Buchenwald (1). The largest transports went to Auschwitz (see Table 1 below); only two of the eleven transports to the concentration camps took more than one hundred prisoners. The rest carried fewer than fifty each. The last transport to Auschwitz left with four prisoners on November 1, 1944; after that, three transports took a total of 56 Jews to Ravensbruck, the last on February 24, 1945.

\begin{tabular}{|l|l|l|l|l|}
\hline & To & Date & Size & Survivors \\
\hline Rome & Auschwitz & October 18, 1943 & 1,020 & 16 \\
\hline $\begin{array}{l}\text { Fossoli, Mantova, } \\
\text { Verona }\end{array}$ & Auschwitz & April 5, 1944 & 609 & 50 \\
\hline Milan Verona & Auschwitz & January 1, 1944 & 605 & 22 \\
\hline Fossoli & Auschwitz & May 16, 1944 & 581 & 60 \\
\hline Fossoli Verona & Auschwitz & June 26, 1944 & 523 & 35 \\
\hline Fossoli & Auschwitz & February 22, 1944 & 510 & 24 \\
\hline Borgo S. Dalmazzo & $\begin{array}{l}\text { Auschwitz, via } \\
\text { Drancy }\end{array}$ & November 21, 1944 & 309 & 10 \\
\hline
\end{tabular}

Table 1. Largest Transports of Jews from Italy. 55

\footnotetext{
47 Sarfatti, The Jews in Mussolini's Italy, 187-189.

48 Ibid., 186; Zuccotti, The Italians and the Holocaust [1996], 101-138.

49 Sarfatti, The Jews in Mussolini's Italy, 197-202; Simon Levis Sullam, The Italian Executioners, 92-100, 108-117; Zuccotti, The Italians and the Holocaust [1996], 139-187.

50 Sonnino, This Has Happened, 78-97.

51 Ibid., 92-98.

52 See, for example, Edda Servi Machlin, Child of the Ghetto: Coming of Age in Fascist Italy: 1926-1946: A Memoir (Crotonon-Hudson: Giro Press, 1995).

53 Cesarani, Final Solution, 668.

54 Picciotto Fargion, Il Libro della Memoria, 28.

55 Ibid., 58-65.
} 
Those deported to Auschwitz were subject to an immediate selection where some were selected for labor, but most were immediately murdered. Primo Levi, who was deported from Fossoli in February 1944, describes the terror:

The door opened with a crash, and the dark echoed with outlandish orders in that curt, barbaric barking of Germans in command which seems to give vent to millennial anger....In less than ten minutes all the fit men had been collected together in a group. What happened to the others...,we could establish neither then nor later: The night swallowed them up, purely and simply. Today, however, we know...that of our convoy no more than ninety-six men and twenty-nine women entered the respective camps of Monowitz-Buna and Birkenau, and that of all the others, more than five hundred in number, not one was living two days later. ${ }^{56}$

Those not sent to Auschwitz were sent to other concentration camps in Germany. Most of these were Libyan Jews who had been brought to the Italian mainland in 1942.57 The Germans had set up camps such as Buchenwald, Bergen-Belsen, and Flossenberg before the war, mainly as places to send dissidents and criminals. As the war progressed, more and more people, including Jews, were sent there from the camps in the east now overrun by the Soviet Army. By late 1943 until the end of the war in 1945, overcrowding and consequent disease and starvation killed tens of thousands.

The exact mortality rates in these camps may never be known. However, inmates sent to concentration camps did have some chance of surviving; while most died of starvation, disease, and overwork in the camps, some escaped to the forests where they were hidden by peasants or fought as partisans, others fled to larger cities and hid or passed as Christians, and there were others who had valuable skills and were protected until late in the war, giving them a greater chance of survival. 58

\section{Data and Methods}

Data for this paper include information on all 6,775 Jews deported from Italy from September 1943 to March 1945 during the German occupation. The data are drawn from Liliana Picciotto's compilation of basic biographies on all Italian Jews rounded up and sent east. ${ }^{59}$ Around $95 \%$ of the deaths of Italian Jews (and foreign Jews living in Italy) occurred among those on the transports. 60

\footnotetext{
56 Primo Levi and Paul Bailey, If This Is a Man and The Truce, trans. Stuart Woolf, reprint edition (London: Abacus, 2003), 19; Some slave laborers, including Levi, were sent to the Monowitz-Buna works, known as Auschwitz III, a chemical plant run by I.G. Farben. The average life expectancy for Jewish workers sent there was three or four months. See Florian Schmaltz, The Life Expectancy at the Buna Monowitz Concentration Camp (Frankfurt am Main: Norbert Wolllheim Memorial, 2010), 1-8, accessed November 14, 2020, https:/ / www.yumpu.com/en/document/ view/5012796/pdf-florian-schmaltz-the-death-toll-at-the-buna-wollheim-.

57 U.S. Holocaust Memorial Museum, Holocaust Encyclopedia Italy.

58 Evgeny Finkel, Ordinary Jews: Choice and Survival during the Holocaust (Princeton; Oxford: Princeton University Press, 2017).

${ }^{59}$ Picciotto Fargion, Il Libro della Memoria.

${ }^{60}$ Calculated from ibid., 28. A few of those transported were Sinti (Gypsies). Picciotto's information was collected under the auspices of the Fondazione Centro de Documentazione Ebraica Contemporanea in Milan, Italy. Further information can be found at the U.S. Holocaust Memorial Museum website; although the full database has not been deposited there. See "Holocaust Survivors and Victims Database: A Computerized Database Was Created By Dr. Liliana Picciotto Fargion of The Fondazione Centro De Documentazione Ebraica Contemporanea (Id: 31522)," U.S. Holocaust Memorial Museum, accessed on March 24, 2019, https://www.ushmm.org/online/hsv/ source view.php?SourceId=31522. The analysis omits the Aegean islands that had been under Italian control and from which there was a massive deportation of Jews in July 1944, destroying most of the age-old Jewish populations there.
} 
Our database consists of information on the transport and the individual deported. Transport characteristics include the departure point, date, and destination. Individual characteristics include age, gender, and fate, that is, whether they were liberated, gassed on arrival, died on the transport itself, or died in Auschwitz or one of the other camps. Those who died in the camps a few days after liberation were coded with deaths other than gas. Where known, the place of death was also coded, but $40 \%$ were unknown.

We will test two hypotheses concerning gender, three hypotheses concerning age, and two hypotheses looking at interaction of gender and age:

1. We expect that women were more likely than men to a) be gassed on arrival at Auschwitz and b) to have higher overall mortality rates.

2. We expect that those over 60 (the old) and under 15 (the young) were more likely to be sent to Auschwitz than the middle-aged group.

3. We expect that the old and the young were more likely to a) be gassed on arrival at Auschwitz and b) be less likely to survive than those in middle age groups.

4. Finally, we expect an interaction between sex and age, with women in child-bearing and child-rearing ages (15-44) more likely than similar aged men to be gassed on arrival at Auschwitz and less likely to survive.

\section{Findings}

Table 1 indicates that $53 \%$ of those transported from Italy were men, quite different from the overall Western European transports where 56\% were women.

The impact of gender on the fate of Italian Jewish deportees

Men and women were deported in roughly similar proportions to Auschwitz, on the one hand, and concentration camps on the other (see Table 2). A few more women than men were sent to Bergen Belsen and Ravensbruck, which was mostly a woman's camp. No women were sent to Flossenberg. Equal proportions were sent to Buchenwald, and equal proportions were unknown.

\begin{tabular}{|l|l|l|l|}
\hline & $\%$ & $\%$ Men & $\%$ Women \\
\hline Auschwitz & 82 & 83 & 81 \\
\hline Bergen-Belsen & 6 & 5 & 7 \\
\hline Ravensbruck & 2 & 1 & 3 \\
\hline Flossenburg & 1 & 1 & 0 \\
\hline Buchenwald & 0.3 & 0.6 & 0 \\
\hline Unknown & 9 & 9 & 9 \\
\hline Total & $100(6,775)$ & $100(3,557)$ & $100(3,197)$ \\
\hline
\end{tabular}

Table 2. Destinations of Deported Italian Jews.

These findings can be compared to another analysis of transports from all over Western Europe where women were somewhat more likely to be sent to both Terezin and the killing camps. ${ }^{61}$ However, these differences appeared to be due to the time in the war that deportations occurred. By the time that the Italian Jews were deported, the killing camps and the ghettos,

61 Welch, Gender and Selection. 
except for Lodz, were closed. Most of the rest of Western European Jews had already been transported. Terezin was open but Germans chose not to direct Italian transports there. The late arrival of Germans in Italy after the killing camps had all closed may explain much of the difference between Italy and the other Western European countries. ${ }^{62}$

To examine the proportion gassed, we will examine only deportees to Auschwitz, since none of the other camps to which the Italian Jewish population were sent had a selection process on arrival where some were sent to be immediately gassed. In most Auschwitz transports, before anyone was registered in the camp, amidst shouts, screams, beatings, and snapping dogs, the passengers were sent to one side for an immediate walk to the gas chamber, or to the other, for temporary reprieve as a slave laborer. The shock of arrival overwhelmed most people who survived to write about it. Piera Sonnino, for example, writes of her family's arrival on a freezing end-of-October day:

I feel like I had entered a dimension where nothing is human, that is utterly hostile to everything human, a dimension that has absorbed even its own creators...a cold machine muddy and dark, fatal and inexorable, topped by a small flame that I see for an instant as in the distance it breaks the darkness, as if the sky were burning. I don't know yet what it is. ${ }^{63}$

Hundreds of survivors' reports indicate that old people, children, mothers with children, those with evidence of even mild disabilities, such as wearing glasses, and others who did not look fit to work were sent directly to the gas chambers. Working-aged men and women who looked fit, except for women with small children, were often kept alive for slave labor. There were many life and death moments for prisoners at Auschwitz, and this was the first. Piera Sonnino describes how she and her sisters were placed in one group and taken away, her older brothers in another group, and her parents in a third. It wasn't until later that day that she learned from another prisoner that her parents had likely already been murdered. ${ }^{64}$

Men and women assigned to slave labor were registered and given a number. Those sent directly to the gas chambers were not registered. An analysis of 253 transports to Auschwitz from all over Western Europe found that about $57 \%$ of the prisoners were gassed immediately. 65

Overall, Italian Jews were sent to immediate death at Auschwitz at a much lower rate than those prisoners on other Western European transports. Italian Jewish women were significantly more likely to be gassed on arrival at Auschwitz compared to their male counterparts (see Figure 1 below), a finding consistent with overall Western European patterns. The difference between men and women is about $10 \%$ and is statistically significant. Our expectation is supported by these data.

\footnotetext{
62 Yitzhak Arad, Belzec, Sobibor, Treblinka: The Operation Reinhard Death Camps (Bloomington: University of Indiana Press, 2018).

63 Sonnino, This Has Happened, 97-98.

${ }^{64}$ Ibid., 104 . Her mother was 58, her father 64 . Only Piera of their family of eight survived even though all six teen-aged and adult children survived the initial selection.

65 Ibid. These data are from the 194 of 290 Auschwitz transports for which there are gender data.
} 


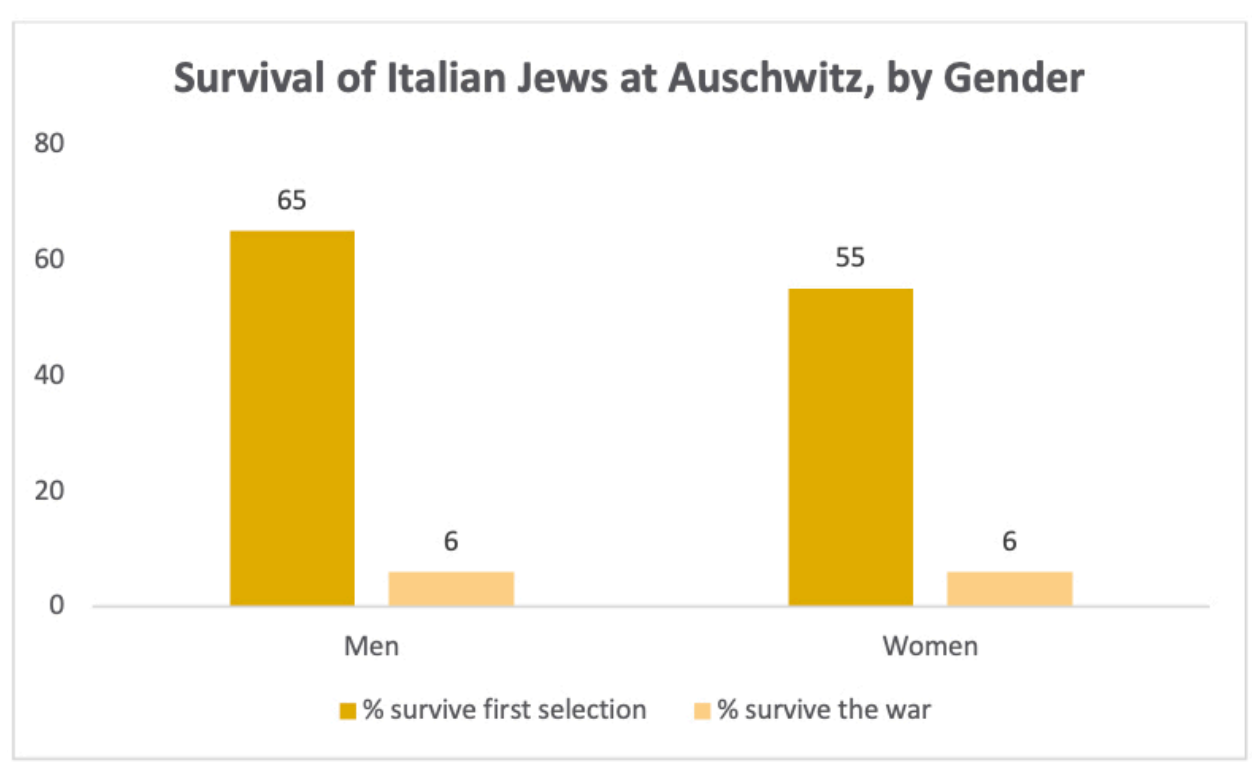

Figure 1. $N=5566$. Gender differences in surviving the first selection are significant at .01, gender differences in overall survival are not significant.

However, contrary to our expectation, as the figure also shows, the overall survival rate of men and women sent to Auschwitz was nearly identical. The starvation, murders, disease, brutality, and inhumane working conditions at Auschwitz and its subcamps killed nearly five out of six women who were sent to slave labor and an even higher proportion of men.

Survival rates of Italian Jews not sent to Auschwitz were considerably higher. Of the 557 deported Italian Jews not sent to Auschwitz, $74 \%$ survived to liberation. Women were significantly more likely to survive than men, $78 \%-70 \%$ (sig at < .05). Unfortunately, around $90 \%$ of those whose destinations we know were sent to Auschwitz.

Taking into account both those sent to Auschwitz and those who went to labor camps, the overall survival rate of Italian Jews was 12\% for men and $13 \%$ for women (difference not significant). The slight advantage for women is entirely due to the better survival rates of those sent to labor camps.

The impact of age on the fate of Italian Jewish deportees

Though official statistics collected at Auschwitz do not record information on ages of individuals, voluminous anecdotal evidence tells us that elderly people and children were much more likely to be immediately murdered than working-age men and women. One study of survival among Amsterdam Jews also documented the much smaller chances of survival among older people. The study, based on the entire Jewish population, not just those deported, documented higher rates of survival among the very young who were often hidden and deported in smaller proportions than those who were older. ${ }^{66}$ But we have no information about how general this pattern was.

In Figure 2, we examine the relationship between age and the probability of execution on arrival at Auschwitz and on survival among all the Auschwitz deportees. We coded age into broader groups reflecting likelihood of survival: less than 5-years, 5-14 years, 15-30 years, 31-45 years, 45-59 years, and older than 60.

66 Tammes, Surviving the Holocaust. 


\section{Survival of Italian Jews at Auschwitz by Age}

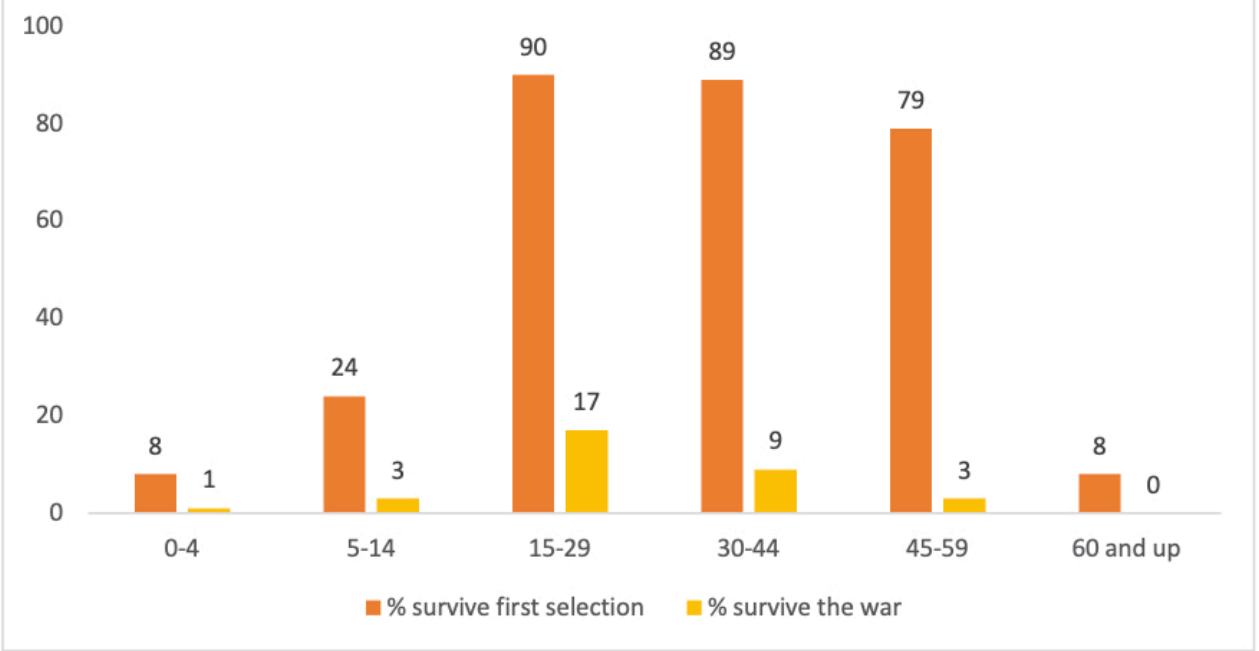

Figure 2. Age differences in surviving first selection and surviving the war are each statistically significant at .001 . N's range from 208 for the youngest group and 440 for the 5-14 group; to 1,334 for the 45-59 age group, 1,257 for the 60 and over group, and 1,250 for the 30-44 cohort. There were 959 aged 15-29.

Less than $10 \%$ of toddlers survived the initial selection. Most of those aged 5-14 years were also immediately murdered. Those few who survived at this stage were teenagers who must have looked older than they were. Indeed, more than 70\% of those aged 12 but less than $20 \%$ of those aged 13 and 14 were immediately murdered. Many young teen-aged survivors report they told the selection officer they were older than they were or were advised to do so. During the initial selection at Auschwitz, Elli Friedmann, aged 13 from Somorja, Hungary, was told by Dr. Joseph Mengele himself to say she was 16. He exclaimed "Goldenes Haar," (Golden Hair) and touched her blond braids. ${ }^{67}$ Ruth Kruger, from Vienna, was forever grateful to a young women clerk assisting with selection in her Auschwitz barracks. She whispered to Ruth to say she was 15 , not 13 , and then commented to the officer making the selection that Ruth looked strong. ${ }^{68}$ Almost all of those in the 15-44 age groups survived the initial Auschwitz selection, along with nearly $80 \%$ of those in the $45-59$ group.

On the other hand, only $8 \%$ of those sixty and older survived their first day at Auschwitz. There were no clear patterns by age among those 60 and over suggesting that it was the appearance of strength and vigor that mattered.

As we saw in Figure 1, being sent to slave labor on the prisoner's first day did not mean that one would survive Auschwitz. After surviving the first selection, chances of survival until liberation were only one in eight if one was under 15-years-old, but only one in about ten for those from 30-44 and almost one in twenty for the 45-59 group. The highest survival rate was $17 \%$ among those aged 15-29. Among those 1,257 Italian Jews who were 60 and older, no one survived Auschwitz.

The possibilities of survival in the other camps were considerably better than probabilities of survival at Auschwitz in all groups. All of the 43 young children survived, and a majority of the rest did too except among the oldest cohort. Even though the N's are small, the survival of the youngest cohorts is remarkable.

Taking into account those who were sent to Auschwitz and those sent elsewhere, chances of survival until liberation were low (see Table 3 below), though it varied substantially among age groups. Only $2 \%$ of those over 60 and $6 \%$ of those from $45-59$ survived to the end of

\footnotetext{
${ }^{67}$ Livia E. Bitton-Jackson, Elli: Coming of Age in the Holocaust, 1st ed. (London: HarperCollins Publishers, 1980), 74-75.

${ }^{68}$ Ruth Klüger, Still Alive: A Holocaust Girlhood Remembered (New York: Feminist Press at the City University of New York, 2001), 107-108.
} 
the war. The hardships of the labor camps, the starvation diets, and the typhus and other diseases took their greatest toll on the oldest. But the survival rate of young adults was not high either. The highest survival rate was among the 15 to 29 -year-olds where $24 \%$ survived, onethird more than either the next youngest or next oldest cohort.

Overall, then, we have seen large differences among men and women in the first selection at Auschwitz, significant gender differences in survival in labor camps, and small to negligible gender differences in survival at Auschwitz and overall survival. Now we turn to the interaction of gender and age and its impact on survival.

\begin{tabular}{|l|l|l|l|l|l|l|}
\hline Years of age & $\begin{array}{l}\text { Less } \\
\text { than 5 }\end{array}$ & $\mathbf{5 - 1 4}$ & $\mathbf{1 5 - 2 9}$ & $\mathbf{3 0 - 4 4}$ & $\mathbf{4 5 - 5 9}$ & $\begin{array}{l}\mathbf{6 0} \text { and } \\
\text { over }\end{array}$ \\
\hline $\begin{array}{l}\text { \% of deportees to } \\
\text { labor camps who } \\
\text { survived to } \\
\text { liberation }\end{array}$ & 100 & 90 & 79 & 78 & 55 & 45 \\
\hline $\begin{array}{l}\text { \% all deportees } \\
\text { who survived to } \\
\text { liberation }\end{array}$ & 17 & 16 & 24 & 17 & 6 & 2 \\
\hline $\begin{array}{l}N^{\prime} \text { s of labor camp; } \\
\text { all deportees }\end{array}$ & $43 ; 264$ & $86 ; 547$ & $128 ; 1,554$ & $142 ; 1,497$ & $96 ; 1,579$ & $49 ; 1,526$ \\
\hline
\end{tabular}

Table 3. Italian Jews' Survival in Labor Camps and Overall.

*Both relationships significant at .01. $N$ of those deported to labor camps $=544$, overall $=6,566$.

The combined impact of gender and age on the fate of Italian Jewish deportees

Figure 3 further illustrates the relationship between sex, age, and being murdered on arrival at Auschwitz and on survival. Age is arrayed by five-year increments, with the youngest being younger than five and the oldest category, 85 and older.

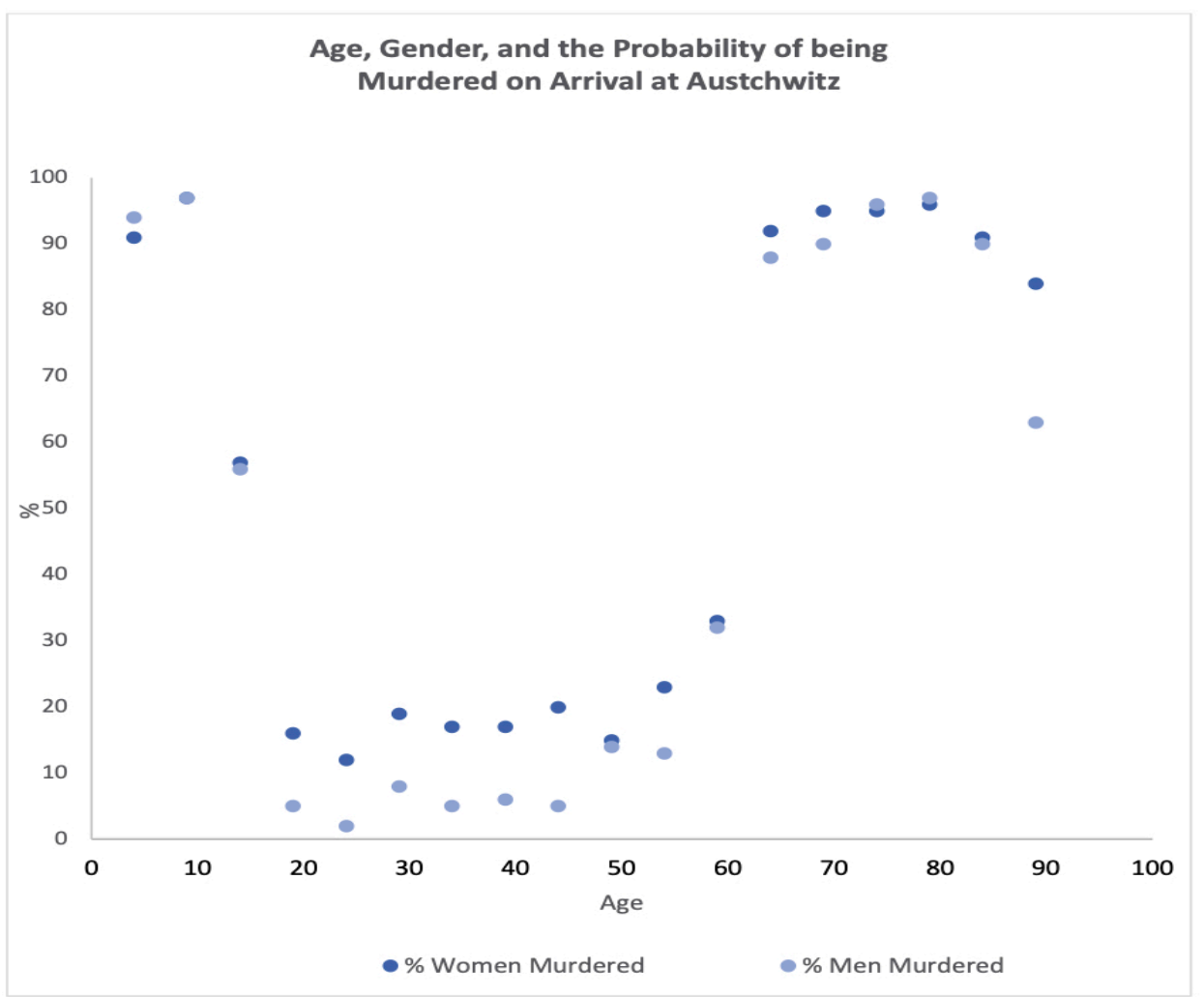

Figure 3. Includes only those sent to Auschwitz $(N=5,588)$. 
Figure 3 confirms dramatically the common wisdom about selection at Auschwitz and specifies the differences that were found. The fate of very young men and women (and girls and boys) and older men and women was nearly identical, with almost all being sent immediately to the gas chambers to be murdered. There are striking differences between the 5-9 age group, where almost all are murdered and the 10-14 cohort, where a significant minority of both boys and girls survive that initial selection. At 15, the proportion sent to immediate death falls again. At the other end of the age structure, most men and women aged 55 survive the selection and most 60 or over die. There is only one anomaly in the data, with a few men in the oldest category ( 85 and over) not being immediately murdered.

The significant gender differences come in the young adult and adult categories. Women are much more likely than men to be executed if they are between 15 and 44 . Some women of these ages are pregnant and many had children of less than 15, factors leading to immediate death. It would be surprising that women in their mid-teens fit this profile, but some of them may have looked childish and been treated like children slightly younger, while the older members of this 15-19 cohort may have had infants or toddlers or been in care of younger siblings.

The anomaly here is that women and men differ in the 55 to 59 -year-old span too, an age when women are unlikely to have small children. In this age group, men are executed at a rate more like those in the immediately younger cohort, while women are part way between the younger and older cohorts. Of course, the brief biographies do not report the health status of anyone, and it may be that women in this age group are sicker, frailer, or appear older than the men. They may have been with grandchildren. By 60 , both men and women are clearly seen as not able to work and the proportion murdered immediately increases dramatically. Our expectation about gender and age differences in the initial selection at Auschwitz was confirmed.

As we indicated above, men's larger chance of surviving the initial selection does not give them a bigger chance of survival. Figure 4 below illustrates overall survival at Auschwitz. In only one age cohort, ten to fourteen, are gender differences significant and in that case, girls are more likely to survive than boys. In the next older cohort, 15-19, somewhat more men than women survive, but the difference is not significant. In the young and middle age cohorts there are no differences between men and women. And as we noted, no one from Italy in the oldest age cohorts survived Auschwitz.

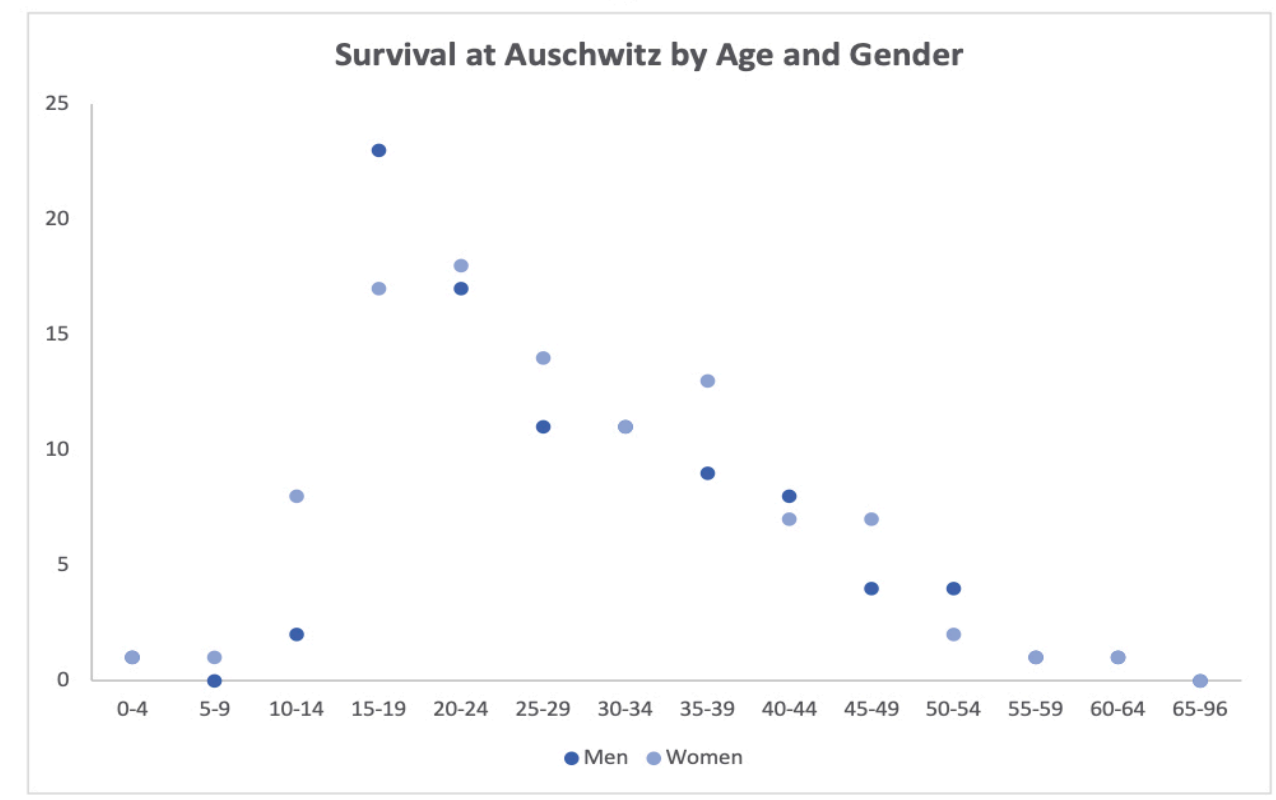

Figure 4. Includes only those sent to Auschwitz $(N=5,588)$. 
As we described earlier, survival was much higher among those sent to labor camps than those sent to Auschwitz. An examination of the 544 people sent to labor camps for whom we have age and gender data indicates there are no gender differences in survival in each age category. Age, rather than gender, determined survival in these camps. The slightly greater chance of women surviving labor camps overall is because a higher proportion were in the 1529 age group where survival was higher and less likely to be in the oldest group which had the lowest survival rates.

Examining differences in survival amongst both of those sent to Auschwitz and those sent to labor camps, we find that, in most age cohorts, a slightly greater proportion of women than men survive (see Figure 5 below). The exception is the very oldest cohort (85-years and older), where men appear more likely to survive the war. That is because the only person surviving in the 44-person cohort was a man. In most age cohorts, men and women's survival rates were about equal, with $4 \%$ more women surviving in the $35-39$ age cohort.

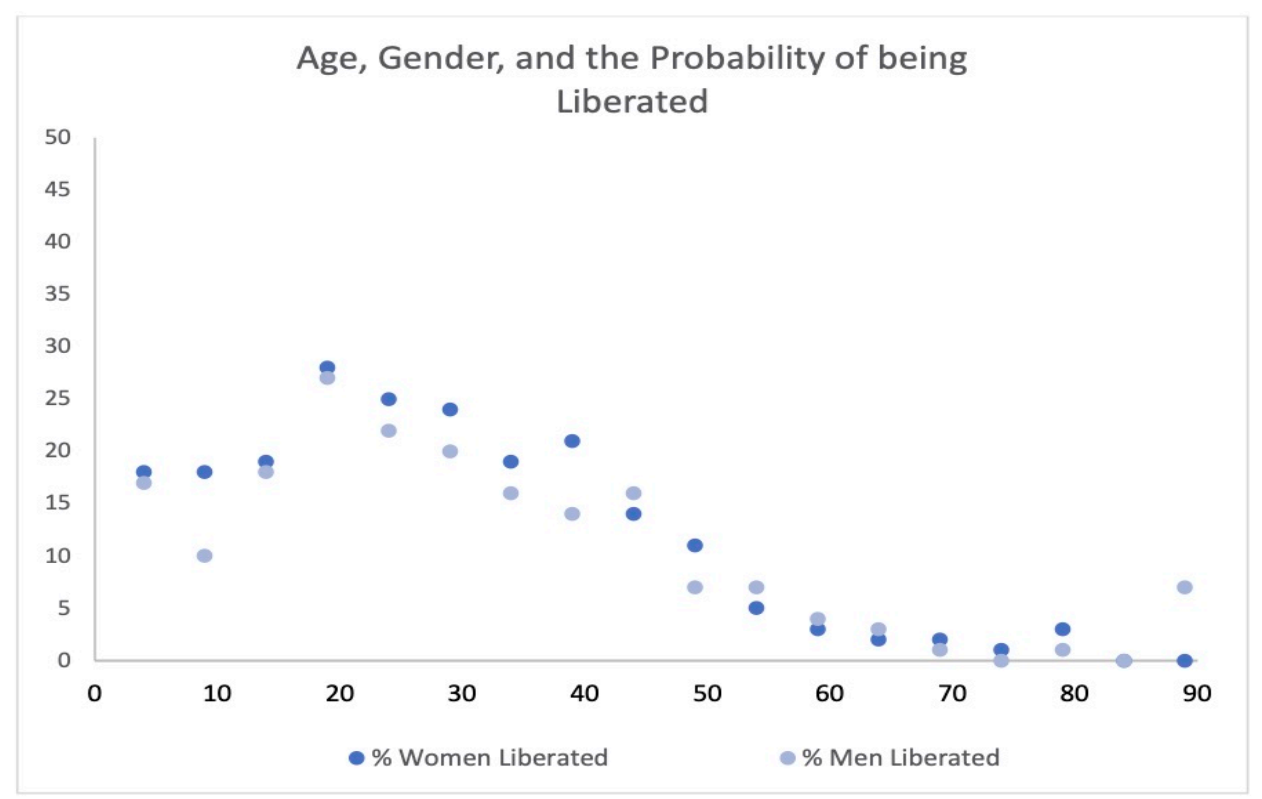

Figure 5. $N=6,554$. No gender differences were significant within age categories except the 5-9 year olds.

Of note, in the age categories where women were more likely to be immediately murdered at Auschwitz, gender differences in overall survival were nil.

In the final analysis, we add the year of transport to factors predicting being gassed on arrival at Auschwitz and overall survival. We regressed whether or not one was gassed on arrival on dummy variables measuring gender, the age categories used in Table 1, interaction terms for gender and the ages where women are more likely to be murdered immediately, and the time of the transport: in 1943 (the omitted category), early 1944, late 1944, and 1945. The 1945 dummy variable is not included because arrivals were not sent to Auschwitz after November 1944 and the Soviet army liberated the camp in January 1945.

Table 4 below summarizes the impact of these factors. Being deported in early 1944 reduced chances of being sent to the gas chamber by $4 \%$ compared to 1943. Age was a significant factor throughout, with those aged 5-14 and those 60 and over being significantly more likely to be gassed on arrival than the up-to- 4 age group. As documented in the earlier analysis, all other groups, from 15-49, were significantly less likely to go to the gas chambers.

Controlling for age, women were about 3\% more likely than men to be selected for the gas chambers on arrival but women in the 15-29 age group were $10 \%$ more likely and in the 3044 group $6 \%$.

Of note, the factors in this equation predict over half the variation in those selected to be murdered on arrival. But other factors also made a difference, especially appearance. Those who 
appeared weak or disabled were likely to be sent to be murdered no matter what their ages were. Then, there is a matter of luck, as exemplified by the stories of Ruth and Elli cited above. Looking like an older teenager rather than a younger one or a younger woman instead of an older one; having blond hair; or being able to hide a minor disability all mattered.

This model illustrated in Table 4 does not fit survival very well. That is because time of transport is very highly correlated with being sent to Auschwitz and we have seen that the survival rates of those sent to Auschwitz are much lower than those sent to labor camps. All Italian transports that left in 1943 went to Auschwitz as did $90 \%$ of those in the first half of 1944 and $76 \%$ in the second half of 1944 . Conversely, no 1945 transport went there.

\begin{tabular}{|l|c|c|c|}
\hline \multirow{2}{*}{} & \multicolumn{2}{|c|}{ Unstandardized Coefficients } & \multirow{2}{*}{$\mathrm{t}$} \\
\cline { 2 - 3 } & $\mathrm{b}$ & Std. e & $29.75^{*}$ \\
\hline (Constant) & .61 & .02 & $-4.13^{*}$ \\
\hline Transport, first half 1944 & -.04 & .01 & -1.63 \\
\hline Age 5-14 & -.03 & .02 & $6.20^{*}$ \\
\hline Age 15-29 & .16 & .03 & $-20.92^{*}$ \\
\hline Age 30-44 & -.53 & .03 & $-22.04^{*}$ \\
\hline Age 45-59 & -.52 & .02 & $-17.83^{*}$ \\
\hline Age 60 and over & -.38 & .02 & $15.31^{*}$ \\
\hline Women & .33 & .02 & $2.70^{*}$ \\
\hline Women age 15-29 & .03 & .01 & 2.61 \\
\hline Women age 30-44 & .07 & .03 & 2.79 \\
\hline
\end{tabular}

Table 4. Predictors of Selection for Murder on Arrival at Auschwitz

${ }^{*} \mathrm{~F}=549.6$, significant at $.00, \mathrm{R}^{2}=.50$. Omitted categories are ages $0-4$ and $1943 . N=5,543$.

In Table 5 below, we examine gender differences in survival by year of transport. From the 1943 transports, men were significantly more likely to survive, but in the 1944 transports, women were. In the first half of 1944, the peak of the Italian transports, women's survival rate slightly exceeded that of men, an advantage that grew in the second half of the year. As we saw in Figure 1, overall survival was almost identical. These patterns are mirrored if we add transports to labor camps to those from Auschwitz. Men had a significantly higher survival rate from the 1943 transports and women in 1944. Survival rates in the forty-three people on the 1945 transports was about equal. 69

\begin{tabular}{|l|c|c|c|}
\hline & Men & Women & $N$ \\
\hline 1943 & 5 & $1^{*}$ & 1,838 \\
\hline 1944-first half & 6 & $9^{*}$ & 3,127 \\
\hline 1944-second half & 8 & $16^{*}$ & 544 \\
\hline Overall & 6 & 6 & 5,566 \\
\hline
\end{tabular}

Table 5. Percent Surviving at Auschwitz by Gender and Year of Transport.

${ }^{*}$ Gender differences significant at .01 .

\footnotetext{
${ }^{69}$ I initially thought that these differences could reflect age differences between men and women in each year, but they do not. For example, women comprised more of the elderly even in 1944 where their overall survival rate was higher.
} 


\section{Conclusions}

Tracking the fate of European Jews who lived through or died in the Holocaust is a monumental task. We have a rough idea of how many died in each country, but accurate data on who lived and who died in communities are still being painstakingly compiled. Without such analyses, it is impossible to assess the fate of different populations within the Jewish community.

Though the Italian Jewish men and women who were deported were only a small fraction of all Jews sent to labor camps, death camps, and Auschwitz, having a complete picture of each on an individual basis allows us to home in on the factors that led to survival or death. The data included in this article are inclusive of all Jews deported from Italy to Germany and the east.

The analysis sheds new light on old verities but also offers different perspectives. Our understanding of gender and survival in the Holocaust was sharpened. As many have reported, women and children were much more likely to be sent to the gas chamber on arrival at Auschwitz. We documented substantive and statistically significant differences between men and women in immediate execution at Auschwitz. Differences in the 15-44 age group were large, yet most Italian Jewish women survived the first day's selection for the gas chambers.

However, men's higher survival rates on their first day did not lead to better overall survival rates at Auschwitz. The conditions of labor at Auschwitz and its subcamps sentenced almost everyone who survived their first days to death before liberation. And thus, unexpectedly, overall survival rates at Auschwitz for women and men among the Italian Jewish deportees were equal. The toll of starvation, disease, filth, and later selections on the survival of those sent to do hard labor meant that death came to most of those initially spared from the gas chamber.

The analysis also increased our knowledge of the proportions of different age groups who were put to death on arrival at Auschwitz. The overall impressions that it was the young and old and women were certainly confirmed, but there were a few children who were not executed on arrival. We can only guess about why that was. We know that some children, especially twins, were taken for medical experiments. ${ }^{70}$ We have argued that some of those aged 13 and 14 might have been judged to be older and able to work.

However, also as we had expected, survival rates for the elderly were negligible. Most sent to Auschwitz were murdered on arrival. Why were some spared? Perhaps they looked younger than they were. Even so, all those elderly who survived that first selection died in Auschwitz before liberation. A few survived in other labor camps but overall, the survival rate was very low for all cohorts over 60 .

The period of deportations in Italy was short compared to other countries and that fact increased overall survival rates. By the time Italian Jews were transported, the killing camps were closed. That said, in 1943, all were sent to Auschwitz where the probability of survival was minimal. Probabilities of survival were higher for those transported in 1944, even for those sent to Auschwitz. These data support the conclusions about all transported Western European Jews, based on transports, not individuals. ${ }^{71}$ Survival rates were tiny for those transported in 1941 and 1942, were slightly higher in 1943, and then much higher in 1944. Almost everyone survived 1945 transports.

There are significant caveats to our findings. The study did not look at overall survival of Italian Jews, only those who were deported. However, almost all Italian Jews who died did so as a result of deportation. About three hundred died in Italy. ${ }^{72}$ The great majority of the Italian Jewish population was not deported, and thus the $87 \%$ survival rate of Italian Jews is estimated to be the highest in Western Europe except for Denmark. The low death rate within Italy contrasted with the high mortality of those deported is similar throughout Western Europe but

\footnotetext{
${ }^{70}$ Debórah Dwork and Robert Jan van Pelt, Auschwitz, 1st ed. (New York: W. W. Norton \& Company, 2002), 338-339; Lifton, The Nazi Doctors; Rees, The Holocaust, 357-358.

71 Welch, Gender and Selection.

72 Picciotto Fargion, Il Libro della Memoria, 28.
} 
very different from the Shoah in Eastern Europe. Nonetheless, the findings of gassing and survival for those who were deported may be relevant to other national populations where larger proportions of the Jewish population were deported.

Despite these caveats, we have learned more precisely the relative fate of men and women and older and younger Italian Jews. We have also estimated the impact of timing of deportation on the survival rates of those deported. Thus, our findings, while limited, add to our understanding of history's largest genocide.

\section{Bibliography}

Arad, Yitzhak. Belzec, Sobibor, Treblinka: The Operation Reinhard Death Camps (Bloomington: University of Indiana Press, 2018).

Baer, Elizabeth R. and Myrna Goldenberg, eds. Experience and Expression: Women, the Nazis, and the Holocaust. Detroit: Wayne State University Press, 2003.

Bergen, Doris. "What Do Studies of Women, Gender, and Sexuality Contribute to Understanding the Holocaust." In Different Horrors, Same Hell: Gender and the Holocaust, edited by Myrna Goldenberg and Amy Shapiro, 16-37. Seattle: University of Washington Press, 2014.

Bernstein, Sara Tuvel. The Seamstress: A Memoir of Survival. New York: The Penguin Group, 1999.

Bitton-Jackson, Livia E. Elli: Coming of Age in the Holocaust, 1st ed. London: HarperCollins Publishers, 1983.

Bos, Pascale Rachel. "Women and the Holocaust: Analyzing Gender Differences." In Experience and Expression: Women, the Nazis, and the Holocaust, edited by Elizabeth R. Baer and Myrna Goldenberg, 23-52. Detroit: Wayne State University Press, 2003.

Browning, Christopher R. Remembering Survival: Inside a Nazi Slave-Labor Camp, 1st ed. New York: W. W. Norton \& Company, 2010.

Capogreco, Carlo Spartaco. "The Fascist Concentration Camps: From Internment to Deportation: Concentration Camps and Jews in Italy during World War II." Primo Levi Center (blog), November 5, 2015. Accessed October 29, 2020. https:// primolevicenter.org/printed-matter/the-fascist-concentration-camps/.

Cesarani, David. Final Solution: The Fate of the Jews 1933-1949. New York: St. Martin's Press, 2016.

Cole, Tim. Holocaust Landscapes. London: Bloomsbury, 2016.

Dwork, Debórah, and Robert Jan van Pelt. Auschwitz. 1st ed. New York: W. W. Norton \& Company, 2002.

Eger, Edith Eva. The Choice: Embrace the Possible. New York: Scribner, 2017.

Erben, Eva and David Lawson. Escape Story: How a Young Girl Survived the Holocaust. Birmingham: Sharron Publishing Services Ltd, 2011.

Fangrad, Alana. Wartime Rape and Sexual Violence: An Examination of the Perpetrators, Motivations, and Functions of Sexual Violence against Jewish Women during the Holocaust. Bloomington: AuthorHouse, 2013.

Finkel, Evgeny. Ordinary Jews: Choice and Survival during the Holocaust. Princeton: Princeton University Press, 2017.

Gerlach, Christian. The Extermination of the European Jews. Cambridge: Cambridge University Press, 2016.

Gigliotti, Simone. The Train Journey: Transit, Captivity, and Witnessing in the Holocaust, 1st ed. New York: Berghahn Books, 2009.

Glass, David V. "Fertility Trends in Europe since the Second World War." Population Studies 22, no. 1 (March 1968), 103-146. Accessed November 2, 2020. https://doi.org/ $10.2307 / 2173355$.

Goldenberg, Myrna. "Sex Based Violence and the Politics and Ethics of Survival." In Different Horrors, Same Hell: Gender and the Holocaust, edited by Myrna Goldenberg and Amy H. Shapiro, 99-128. Seattle: University of Washington Press, 2013. 
Goldenberg, Myrna and Amy H. Shapiro, eds. Different Horrors, Same Hell: Gender and the Holocaust. Seattle: University of Washington Press, 2013.

Hedgepeth, Sonja M., and Rochelle G. Saidel, eds. Sexual Violence against Jewish Women during the Holocaust, 1st ed. Lebanon: Brandeis, 2010.

Hilberg, Raul. "Men and Women." In Perpetrators, Victims, Bystanders: The Jewish Catastrophe 1933-1945, Part II Victims, 126-130. New York: Harper Collins, 1992.

-------. Perpetrators, Victims, Bystanders: The Jewish Catastrophe 1933-1945. New York: Harper Collins, 1992.

Kaplan, Marion A. Between Dignity and Despair: Jewish Life in Nazi Germany. Oxford: Oxford University, Press.

. "Keeping Calm and Weathering the Storm: Jewish Women's Responses to Daily Life in Nazi Germany, 1933-1939." In Women in the Holocaust, edited by Dalia Ofer and Lenore J. Weitzman, 39-54. New Haven: Yale University Press, 1998.

King, Charles. "Can There Be a Political Science of the Holocaust?." Perspectives on Politics 10, no. 2 (June 2012), 323-341.

Klein, Gerda Weissmann. All But My Life. New York: Hill and Wang, 1957.

Klüger, Ruth. Still Alive: A Holocaust Girlhood Remembered. New York: Feminist Press at the City University of New York, 2001.

Kwiet, Konrad. "The Ultimate Refuge: Suicide in the Jewish Community Under the Nazis." The Leo Baeck Institute Yearbook, 29, no. 1 (1984), 135-167. Accessed November 2, 2020. https:// doi.org/10.1093/leobaeck/29.1.135.

Lamet, Eric. A Child al Confino: The True Story of a Jewish Boy and His Mother in Mussolini's Italy. Avon: Adams Media, 2011.

Levi, Primo. If This Is a Man and The Truce. Translated by Stuart Woolf. London: Abacus, 2003.

Lifton, Robert Jay. The Nazi Doctors: Medical Killing and the Psychology of Genocide, 2nd ed. New York: Basic Books, 2017.

Linfield, Harry Seebee. "Statistics of Jews." The American Jewish Yearbook 45, no. 1 (September 30, 1943-September 17, 1944), 571-600. Accessed November 14, 2020. https:// www.jstor.org/stable/23602908.

Machlin, Edda Servi. Child of the Ghetto: Coming of Age in Fascist Italy; 1926-1946: A Memoir. Croton-on-Hudson: Giro Press, 1995.

Mann, Carol. "The Gender Dimension of the Holocaust in France." In Women and Genocide, edited by JoAnn DiGeorgio-Lutz and Donna Gosbee, 73-102. Toronto: Women's Press, 2016.

Mariot, Nicolas and Claire Zalc. Face à la persécution: 991 Juifs dans la guerre. Paris: Odile Jacob, Fondacion pour Mémoire de la Shoah, 2010. Kindle.

Mason, Henry L. "Testing Human Bonds Within Nations: Jews in the Occupied Netherlands." Political Science Quarterly 99, no. 2 (1984), 315-343.

Milton, Sybil. "Women and the Holocaust: The Case of German and German-Jewish Women." In When Biology Became Destiny: Women in Weimar and Nazi Germany, edited by Renate Bridenthal, Atina Grossman, and Marion Kaplan, 297-333. New York: Monthly Review Press, 1984.

Ofer, Dalia and Lenore J. Weitzman, eds. Women in the Holocaust. New Haven: Yale University Press, 1999.

Paxton, Robert O. Vichy France: Old Guard and New Order, 1940-1944, 1st ed. New York: Random House, 1972.

Picciotto Fargion, Liliana. Il Libro della Memoria: Gli Ebrei Deportati dall'Italia (1943-1945), 2nd ed. Milano: Mursia, 1991.

Rees, Laurence. The Holocaust: A New History, 1st ed. New York: Penguin Books, 2017.

Ringelheim, Joan. "The Split between Gender and the Holocaust." In Women in the Holocaust, edited by Dalia Ofer and Lenore J. Weitzman, 340-350. New Haven: Yale University Press, 1998. 
"Women and the Holocaust: A Reconsideration of Research." In Different Voices: Women and the Holocaust, edited by Carol Rittner and John K. Roth, 373-418. New York: Paragon House, 1993.

Rittner, Carol and John K. Roth, eds. Different Voices: Women and the Holocaust, 1st ed. New York: Paragon House, 1993.

Roseman, Mark. The Wannsee Conference and the Final Solution: A Reconsideration, 1st ed. New York: Picador Paper, 2003.

Sarfatti, Michele. The Jews in Mussolini's Italy: From Equality to Persecution, 1st ed. Translated by John Tedeschi and Anne C. Tedeschi. Madison: University of Wisconsin Press, 2006.

Schmaltz, Florian. The Life Expectancy at the Buna Monowitz Concentration Camp. Frankfurt am Main: Norbert Wolllheim Memorial, 2010, 1-8. Accessed November 14, 2020, https:// www.yumpu.com/en/document/view/5012796/pdf-florian-schmaltz-the-death-tollat-the-buna-wollheim-.

Sierakowiak, Dawid. The Diary of Dawid Sierakowiak: Five Notebooks from the Lódz Ghetto. Edited by Alan Adelson. Translated by Kamil Turowski. New York: Oxford University Press, 1998.

Sonnino, Piera. This Has Happened: An Italian Family in Auschwitz. Translated by Ann Goldstein. New York: Martin's Griffin, 2006.

Stone, Lewi. "Quantifying the Holocaust: Hyperintense Kill Rates during the Nazi Genocide." Science Advances 5, no. 1 (January 2019), 1-10. Accessed November 2, 2020. https:// doi.org/10.1126/sciadv.aau7292.

Sullam, Simon Levis. The Italian Executioners: The Genocide of the Jews of Italy. Translated by Oona Smyth and Claudia Patane. Princeton: Princeton University Press, 2018.

Szwajger, Adina Blady. I Remember Nothing More: The Warsaw Children's Hospital and the Jewish Resistance. New York: Pantheon, 1991.

Tammes, Peter. "Survival of Jews during the Holocaust: The Importance of Different Types of Social Resources." International Journal of Epidemiology 36, no. 2 (2007), 330-35. Accessed November 2, 2020. https:// doi.org/10.1093/ije/dym006.

. "Surviving the Holocaust: Socio-Demographic Differences Among Amsterdam Jews." European Journal of Population 33, no. 3 (2017), 293-318. Accessed November 2, 2020. https:// doi.org/10.1007/s10680-016-9403-3.

Tec, Nechama. Resilience and Courage: Women, Men and the Holocaust. New Haven: Yale University Press, 2004.

Unger, Michael. "The Status and Plight of Women in the Lodz Ghetto." In Women in the Holocaust, edited by Dalia Ofer and Lenore J. Weitzman, 123-142. New Haven: Yale University Press, 1998.

United States Holocaust Memorial Museum. "Holocaust Encyclopedia: Italy." Washington DC, n.d. Accessed September 24, 2020. https://encyclopedia.ushmm.org/content/en/ article/italy.

Waxman, Zoe. "Rape and Sexual Abuse in Hiding." In Sexual Violence against Jewish Women during the Holocaust, edited by Sonja M. Hedgepeth and Rochelle G. Saidel, 124-137. Lebanon: Brandeis, 2010.

Weitzman, Lenore J. "Living on the Aryan Side in Poland." In Women in the Holocaust, edited by Dalia Ofer and Lenore J. Weitzman, 187-222. New Haven: Yale University Press, 1998.

Welch, Susan. "Gender and Selection During the Holocaust: Transports of Western European Jews to the East." Journal of Genocide Research 22, no. 4 (2020), 459-478. Accessed November 14, 2020. https:// doi.org/10.1080/14623528.2020.1764743.

Wolf, Gerhard. "The Wannsee Conference in 1942 and the National Socialist Living Space Dystopia." Journal of Genocide Research 17, no. 2 (2015), 153-175. Accessed November 2, 2020. https:// doi.org/10.1080/14623528.2015.1027074.

Zuccotti, Susan. The Italians and the Holocaust: Persecution, Rescue, and Survival. Lincoln: University of Nebraska Press, 1996.

. The Italians and the Holocaust: Persecution, Rescue, Survival. New York: Basic Books, 1986. 